\title{
Penerapan Metode Pembelajaran Active Knowledge Sharing Untuk Meningkatkan Aktivitas dan Belajar Siswa Kelas VI di SDN Inpres Cenggu Semester I Tahun Pelajaran 2019/2020
}

\author{
Tris Syamsuddin \\ SDN Inpres Cenggu \\ Email: tris_handayani71@gmail.com
}

\begin{abstract}
Abstrak. Strategi pembelajaran aktif tipe active knowledge sharing merupakan salah satu cara untuk meningkatkan dan membangun keaktifan siswa dalam proses belajarnya. Penelitian ini bertujuan untuk mengetahui Untuk mengetahui penerapan pembelajaran Active Knowledge Sharing dalam meningkatkan aktivitas dan hasil belajar siswa Kelas VI di SDN Inpres Cenggu Semester I Tahun Pelajaran 2019/2020 Jenis ini adalah Penelitian Tindakan Kelas (PTK), Desain Penelitian Tindakan Kelas yang digunakan sesuai dengan model PTK Kemmis dan McTaggart. Setiap siklus meliputi perencanaan (plan), tindakan (action), pengamatan (observation), evaluasi (evaluation) serta refleksi (reflection). Subyek dalam penelitian ini adalah siswa Kelas VI SDN Inpres Cenggu Semester I sebanyak 18 orang. Instrumen yang digunakan dalam penelitian ini adalah soal tes dan lembar observasi. Berdasarkan analisis data yang telah dilakukan maka disimpulkan bahwa: (1) Pembelajaran dengan metode active knowledge sharing memiliki dampak positif dalam meningkatkan hasil belajar siswa yang ditandai dengan peningkatan ketuntasan belajar siswa dalam setiap siklus, yaitu siklus I $(27,78 \%)$, siklus II $(88,88 \%)$. (2) Penerapan metode active knowledge sharing mempunyai pengaruh positif, yaitu dapat meningkatkan aktivitas belajar siswa yang ditunjukan dengan hasil observasi per siklus menunjukkan peningkatan. Pada siklus I keaktifan siswa tergolong cukup aktif dengan persentase $65 \%$. Pada siklus II mengalami peningkatan yang tergolong sangat aktif dengan persentase $95 \%$
\end{abstract}

Keywords: Pembelajaran Active Knowledge Sharing, Akvitas belajar, Hasil belajar

\section{PENDAHULUAN}

Dalam proses pembelajaran terdapat dua pihak yang sinergik, yakni guru mengajar dan siswa belajar. Guru mengajarkan bagaimana siswa harus belajar. Sementara siswa belajar bagaimana seharusnya belajar melalui berbagai pengalaman belajar sehingga terjadi perubahan dalam dirinya dari aspek kognitif, afektif dan psikomotorik. "Keaktifan siswa menjadi unsur amat penting dalam menentukan kesuksesan belajar. Aktivitas mandiri adalah jaminan untuk mencapai hasil belajar yang sejati" (Budiningsih, 2012). Guru yang kompeten akan lebih mampu menciptakan lingkungan yang efektif dan akan lebih mampu mengelola proses belajar mengajar, sehingga hasil belajar siswa berada pada tingkat yang optimal (Ajoku, 2013). Mengembangkan pendekatan/metode pengajaran merupakan salah satu upaya untuk meningkatkan kualitas belajar siswa.

Seorang pendidik dituntut untuk Jurnal Pendidikan Mandala menguasai pendekatan pembelajaran karena dapat membantu pendidik untuk mempermudah tugasnya dalam menyampaikan mata pelajaran tersebut. Pendidik dituntut untuk menerapkan tiga ranah dalam pendidikan yaitu aspek kognitif, afektif, dan psikomotor serta guru diharapkan mampu melihat tingkat kemampuan yang dimiliki oleh siswa, baik itu siswa yang visual, auditorial maupun kinestik.

Hasil observasi pembelajaran di Kelas VI SDN Inpres Cenggu menujukkan bahwa kondisi ideal tersebut di atas belum tercipta. Kenyataan di lapangan, proses pembelajaran bersifat transfer of knowledge, dengan metode presentasi/ konvensional menyebabkan peserta didik cenderung pasif, kurang bergairah, guru kurang menguasai materi dan cenderung monoton, siswa pasif terlihat dari minimnya akivitas yang dilakukan dalam merespon proses pembelajaran, materi pembelajaran hanya untuk dihafal tanpa diberi tahu kegunaan materi tersebut dalam kehidupan nyata. 
Ditemukan pula hasil belajar pada semester ganjil tahun ajaran 2019/2020 yang masih rendah, yakni diperoleh 55,55\%, atau hanya 10 dari 18 siswa.

Sehubungan dengan permasalahan di atas, diperlukan sebuah strategi pembelajaran yang mampu menjadikan siswa termotivasi dan lebih aktif bukan hanya sekedar memahami materi, tetapi juga melibatkan siswa didalam pembelajaran sehingga menjadi bersemangat dan aktif dalam pembelajaran. Karena keterlibatan siswa baik secara fisik maupun mental akan menimbulkan keaktifan yang optimal, sehingga dapat mempengaruhi kualitas belajar siswa. Salah satu metode yang ingin diterapkan dalam penelitian ini adalah metode pembelajaran active knowledge sharing.

Strategi pembelajaran aktif tipe active knowledge sharing merupakan salah satu cara untuk meningkatkan dan membangun keaktifan siswa dalam proses belajarnya (Aprilianti, 2013). Active knowledge sharing merupakan metode yang didasarkan pada mengajukan pertanyaan yang berkaitan dengan materi pembelajaran kepada siswa dan mendapatkan tanggapan dari siswa. Pada metode pembelajaran tersebut membuat siswa untuk siap belajar materi pelajaran dengan cepat dan dapat digunakan untuk melihat tingkat kemampuan siswa dalam kerjasama tim dalam memecahkan suatu permasalahan pada topik pelajaran. Tujuan metode Active knowledge sharing adalah agar metode ceramah yang dikembangkan oleh guru mendapat perhatian siswa, terutama pada kelas yang jumlah siswanya cukup banyak.

Penggunaan strategi ini dapat memotivasi siswa sehingga tertarik untuk mengikuti pembelajaran, karena pada awal pembelajaran siswa telah diberi motivasi berupa pertanyaan yang akan menarik perhatian siswa untuk mengikuti pembelajaran. Sehingga strategi ini mampu menciptakan interaksi antara siswa dengan siswa, dan juga antara guru dengan siswa, karena siswa akan saling bertukar pengetahuan, dan guru akan membahas pendapat-pendapat yang disampaikan siswa, hal ini akan membuat suasana belajar menjadi lebih menarik.

Penerapan metode active knowledge sharing ini diharapkan mampu mengaktifkan dan meningkatkan aktivitas dan hasil belajar siswa dalam proses pembelajaran. Dengan adanya suasana aktif antara guru dengan siswa diharapkan potensi yang ada dalam diri siswa dapat teraktualisasikan sehingga dapat meningkatkan kualitas pembelajaran PKn.

Berdasarkan permasalahan di atas, penulis tertarik untuk melaksanakan penelitian tentang: Penerapan Metode Pembelajaran Active Knowledge Sharing Untuk Meningkatkan Aktivitas dan Belajar Siswa Kelas VI di SDN Inpres Cenggu Semester I Tahun Pelajaran 2019/2020.

\section{METODE PENELITIAN Jenis Penelitian}

Penelitian ini adalah Penelitian Tindakan Kelas (PTK). Penelitian tindakan kelas (PTK) harus tertuju atau mengenai hal-hal yang terjadi didalam kelas (Aqib, 2007) .Desain Penelitian Tindakan Kelas yang digunakan sesuai dengan model PTK Kemmis dan McTaggart.

\section{Waktu dan Tempat Penelitian}

Penelitian ini dilaksanakan di SDN Inpres Cenggu, pada Semester I Tahun Pelajaran 2018/2019.

\section{Subyek Penelitian}

Subyek dalam penelitian ini adalah siswa siswa Kelas VI semester I SDN Inpres Cenggu Tahun Pelajaran 2019/2020 yang berjumlah 18 orang.

\section{Prosedur Penelitian}

Penelitian ini direncanakan dengan melewati beberapa siklus. Pada tiap siklus terdiri dari 4 tahapan, yaitu: 1) Perencanaan, 2) Pelaksanaan Tindakan, 3) Observasi, 4) Refleksi.

\section{Perencanaan}

Perencanaan merupakan perisiapan yang dilakukan sehubungan dengan pelaksanaan pembelajaran dengan metode Active Knowledge Sharing untuk menyelesaikan masalah. Rencana kegiatan yang akan dilakukan pada tahap ini adalah:
a. Guru menjelaskan tujuan pembelajaran materi
b. Guru membagi siswa menjadi 4 kelompok dengan anggota tiap kelompok 7 anak dari jumlah peserta didik 18 anak. 
c. Guru memanggil kelompok, kelompok memilih topik-topik yang telah disiapkan guru, terdapat tugas kelompok dalam topik yang dipilih. Setiap kelompok mengerjakan tugas kelompok pada lembar kerja kelompok, siswa saling membantu satu sama lain.

d. Setelah selesai kelompok mempresentasikan hasil kerjanya secara bergiliran, siswa bersama guru membahas jawaban yang diperoleh dan disimpulkannya.

e. Kegiatan akhir pembelajaran melakukan evaluasi secara tertulis.

2. Pelaksanaan Tindakan dan Pengamatan

a) Pendahuluan

1) Menyiapkan Rencana Pelaksanaan Pembelajaran (RPP)

2) Menyiapkan materi PKn tentang Nilai juang proses perumusan pancasila sebagai dasar Negara yang terangkum dalam modul pembelajaran

3) Membuat instrument penelitian

4) Melakukan pembagian kelompok

5) Presentasi kelompok

b) Inti

Di dalam kelas siswa diharapkan dapat mengikuti proses pembelajaran dengan baik.

1) Mendengarkan saat guru sedang menerangkan materi pembelajaran

2) Menanyakan apa yang belum paham dari materi pelajaran yang disampaikan oleh guru.

3) Melaksanakan atau mengerjakan tugas yang diberikan oleh guru dengan penuh rasa tanggung jawab, cermat, dan tepat.

c) Penutup

1) Guru dengan siswa mengadakan refleksi terhadap proses dan hasil belajar

2) Guru memberi kesempatan siswa untuk bertanya. Apabila siswa merasa kurang paham atas materi yang disampaikan.

Pelaksanaan tindakan merupakan suatu kegiatan dilaksanakannya tahapan pembelajaran yang telah direncanakan. Dalam hal ini sesuai dengan Rencana Pelaksanaan Pembelajaran (RPP) yang telah disiapkan.

3. Observasi

$$
\text { Mencatat hasil pengamatan pada }
$$

catatan lapangan dan lembar observasi. Tindak lanjutnya melakukan diskusi antara peneliti dengan dosen pembibing. Pada saat proses pengamatan, hal-hal yang dilakukan yakni:

a) Saat pembelajaran dengan metode Active Knowledge Sharing maka harus diobservasi kegiatan siswa dan guru dalam prosespembelajaran.

b) Melakukan penilaian hasil dan membuat laporan hasil temuan.

c) Pengumpulan lembar kegiatan siswa dan hasil belajar.

\section{Refleksi}

a) Mengidentifikasi kesulitan dan hambatan pelaksanaan siklus II

Menganalisis hasil pengamatan lembar observasi, catatan lapangan dan hasil tes kemudian dikaji dan refleksi untuk menyempurnakan tindakan.

\section{HASIL DAN PEMBAHASAN}

\section{A. Hasil Penelitian \\ Kondisi Awal Siswa}

Hasil belajar PKn siswa Kelas VI SD Negeri Inpres Cenggu Semester I Tahun Pelajaran 2019/2020 sebelum diadakan penelitian hampir setengah dari jumlah siswa Kelas VI belumlah tuntas KKM ( $\geq 75 \%)$, yaitu $55,55 \%$. Hal ini dikarenakan guru masih cenderung menggunakan ceramah dalam proses pembelajaran. Jadi guru lebih aktif sedangkan siswanya pasif dalam proses pembelajan yang berlangsung. Sehingga siswa tidak secara optimal menyerap materi pelajaran yang disampaikan, siswa akan merasa jenuh dan bosan. Sehingga hasil belajar siswa dalam pelajaran PKn dengan pokok bahasan Nilai juang proses perumusan pancasila sebagai dasar Negara hasilnya rendah. Penelitian tindakan kelas ini menggunakan metode Active Knowledge Sharing diharapkan dapat meningkatkan hasil belajar siswa.

\section{Hasil Siklus I}

Siklus I merupakan langkah awal yang sangat menentukan siklus berikutnya, karena dalam siklus ini terdapat usaha pembenahan dalam proses interaksi antara siswa dan guru dalam pembelajaran. Pada siklus ini pembelajaran dilaksanakan dengan satu kali pertemuan dengan alokasi waktu 2 x 45 menit 
menggunakan metode Active Knowledge Sharing. Pelaksanaan siklus I dilaksanakan dengan beberapa tahap, yaitu:

a) Perencanaan

Pada tahap perencanaan dilakukan kegiatan mempersiapkan rencana pelaksanaan pembelajaran, menyiapkan lembar observasi untuk mencatat aktivitas siswa dalam pembelajaran, lembar kerja siswa, dan menyiapkan soal evaluasi untuk mengetahui ketuntasan belajar siswa. Guru juga mengupayakan agar kondisi kelas kondusif sehingga proses pembelajaran dapat berjalan dengan baik, lancar, dan baik sesuai dengan rencana pelaksanaan pembelajaran.

b) Pelaksanaan Tindakan

Pelaksanaan kegiatan belajar mengajar untuk siklus I dilaksanakan di Kelas VI dengan jumlah siswa 18 siswa. Dalam hal ini peneliti bertindak sebagai guru.

a. Kegiatan awal
Untuk mengawali pembelajaran ini guru membuatan rencana pelaksanaan pembelajaran (RPP) tentang materi yang diajarkan dengan menggunakan metode pembelajaran. Persiapan media yang akan digunakan dalam pembelajaran. Persiapan lembar observasi pembelajaran untuk setiap berlangsungnya pembelajaran Menyusun pedoman observasi dan soal test.

b. Kegiatan inti

Dalam kegiatan inti, waktu eksplorasi guru bertannya sebutkan perubahan lingkungan fisik yang terjadi di daerahmu? guru menampung semua jawaban siswa dan memberikan aplaus untuk semua jawaban siswa. Guru membagi siswa kedalam kelompok secara heterogen, menjadi 4 kelompok dalam kelas. Siswa bergabung dengan tim/anggota masing-masing yang telah ditentukan. Siswa memperhatikan dan mendengarkan penjelasan dari guru cara kerja dalam kelompok. Dalam elaborasi guru, masing-masing kelompok memilih subtopik melalui pertanyaan yang diajukan siswa. Siswa bisa mencari informasi dari buku PKn
Kelas VI Erlangga atau sumber lainnya untuk mendapatkan jawaban dari tugas yang diberikan guru. Siswa berfikir bersama, berdiskusi dan menyatukan pendapat (memutar searah jarum jam) terhadap pertanyaan guru serta meyakinkan tiap anggota dalam timnya mengetahui jawaban tersebut. Sewaktu siswa melakukan kerja kelompok, guru mengamati aktivitas dan memberikan bantuan atau bimbingan seperlunya. Masing-masing kelompok mempresentasikan hasil kerja kelompok. Siswa bersama guru membahas jawaban yang diperoleh dan disimpulkan. Dalam konfirmasi guru bertanya jawab tentang hal-hal yang belum diketahui siswa. Guru bersama siswa bertanya jawab meluruskan kesalahan pemahaman, memberikan penguatan dan penyimpulan.

c. Kegiatan akhir

Dalam kegiatan akhir guru, mengulas sekilas mengenai materi yang dipelajari untuk mengetahui kemampuan siswa dalam penguasaan materi. Guru menyampaikan pembelajaran untuk pertemuan selanjutnya.

c) Pengamatan

Hasil pengamatan siklus I dicatat dalam lemabar observasi yang telah dipersiapkan. Pengamatan siklus I diperoleh $65 \%$ siswa cukup aktif dalam pembelajaran dengan menggunakan metode Active Knowledge Sharing. Adapun hasil belajar siklus I sebagai berikut:

Tabel 1. Hasil Belajar Siklus I

\begin{tabular}{|c|c|c|c|}
\hline \multirow{2}{*}{ No. Res } & \multirow{2}{*}{ Nilai } & \multicolumn{2}{|c|}{ Ketuntasan } \\
\hline & & Ya & Tidak \\
\hline 1 & 50 & & $\sqrt{ }$ \\
\hline 2 & 40 & & $\sqrt{ }$ \\
\hline 3 & 50 & & $\sqrt{ }$ \\
\hline 4 & 50 & & $\sqrt{ }$ \\
\hline 5 & 70 & $\sqrt{ }$ & \\
\hline 6 & 60 & & $\sqrt{ }$ \\
\hline 7 & 60 & & $\sqrt{ }$ \\
\hline 8 & 60 & & $\sqrt{ }$ \\
\hline
\end{tabular}




\begin{tabular}{|c|c|c|c|}
\hline 9 & 60 & & $\sqrt{ }$ \\
\hline 10 & 50 & & $\sqrt{ }$ \\
\hline 11 & 80 & $\sqrt{ }$ & \\
\hline 12 & 40 & & $\sqrt{ }$ \\
\hline 13 & 60 & & $\sqrt{ }$ \\
\hline 14 & 80 & $\sqrt{ }$ & \\
\hline 15 & 80 & $\sqrt{ }$ & \\
\hline 16 & 50 & & $\sqrt{ }$ \\
\hline 17 & 50 & & $\sqrt{ }$ \\
\hline 18 & 80 & $\sqrt{ }$ & \\
\hline Jumlah & 1070 & 5 & 13 \\
\hline Rata-Rata & 59,44 & \multicolumn{2}{|c|}{} \\
\hline Ketuntasan & & $27,78 \%$ \\
\hline
\end{tabular}

d) Refleksi

Berdasarkan hasil pengamatan pada siklus I siswa masih kurang maksimal dalam proses pembelajaran. Adapun yang menjadi kendalanya sebagai berikut:

a. Hasil observasi aktivitas belajar siswa mencapai $65 \%$. Hal ini menunjukkan siswa masih kurang maksimal dalam pembelajaran

b. Siswa belum memahami dengan metode Active Knowledge Sharing

c. Siswa masih kurang antusias dalam proses pembelajaran

Hasil evaluasi pembelajaran pembelajaran pada siklus I dengan metode Active Knowledge Sharing mencapai 27,78\% dari 18 siswa hanya 85 siswa yang nilai hasil belajarnya diatas 73. Hasil tersebut menunjukkan bahwa pada siklus pertama secara klasikal siswa belum tuntas belajar lebih kecil dari persentase ketuntasan yang dikehendaki yaitu sebesar $75 \%$

\section{Hasil Siklus II}

Siklus lanjutan ini juga terdiri dari tindakan perencanaan, pelaksanaan tindakan, observasi dan refleksi.

a) Perencanaan

Perencanaan tindakan pada siklus II ini dilakukan tidak jauh beda dengan siklus I yaitu dengan membuat Rencana Pembelajaran (RP), membuat Lembar Kegiatan Siswa (LKS) dan membuat beberapa soal uji kompetensi siklus II, membuat Lembar Pengamatan Aktivitas Siswa dalam KBM dan Lembar Pengamatan Tinjauan Kelas. Tidak lupa dalam akhir kegiatan selalu dilakukan suatu evaluasi guna mengetahui peningkatan dan perubahan yang dialami oleh siswa selama proses pembelajaran.

b) Pelaksanaan

Pelaksanaan kegiatan belajar mengajar untuk siklus II dilaksanakan di Kelas VI dengan jumlah siswa 18 siswa. Dalam hal ini peneliti bertindak sebagai guru. Adapun proses belajar mengajar mengacu pada rencana pelajaran dengan memperhatikan revisi pada siklus I, sehingga kesalahan atau kekurangan pada siklus I tidak terulang lagi pada siklus II. Pengamatan (observasi) dilaksanakan bersamaan dengan pelaksanaan belajar mengajar. Pada akhir proses belajar mengajar siswa diberi tes formatif II dengan tujuan untuk mengetahui tingkat keberhasilan siswa selama proses belajar mengajar yang telah dilakukan. Instrument yang digunakan adalah tes formatif II.

c) Pengamatan

Hasil pengamatan siklus I dicatat dalam lembar observasi yang telah dipersiapkan. Pengamatan siklus I diperoleh hasil $95 \%$ siswa aktif dalam pembelajaran dengan metode Active Knowledge Sharing. Adapun hasil belajar siswa dapat dilihat pada tabel dibawah ini.

Tabel 2. Hasil Belajar Siklus II

\begin{tabular}{|c|c|c|c|}
\hline \multirow{2}{*}{ No. Resp } & \multirow{2}{*}{ Nilai } & \multicolumn{2}{|c|}{ Ketuntasan } \\
\hline & & Ya & Tidak \\
\hline 1 & 90 & $\sqrt{ }$ & \\
\hline 2 & 80 & $\sqrt{ }$ & \\
\hline 3 & 90 & $\sqrt{ }$ & \\
\hline 4 & 80 & $\sqrt{ }$ & \\
\hline 5 & 90 & $\sqrt{ }$ & \\
\hline 6 & 60 & & $\sqrt{ }$ \\
\hline 7 & 90 & $\sqrt{ }$ & \\
\hline 8 & 100 & $\sqrt{ }$ & \\
\hline 9 & 90 & $\sqrt{ }$ & \\
\hline 10 & 70 & & $\sqrt{ }$ \\
\hline 11 & 90 & $\sqrt{ }$ & \\
\hline 12 & 80 & $\sqrt{ }$ & \\
\hline
\end{tabular}




\begin{tabular}{|c|c|c|c|}
\hline 13 & 80 & $\sqrt{ }$ & \\
\hline 14 & 80 & $\sqrt{ }$ & \\
\hline 15 & 80 & $\sqrt{ }$ & \\
\hline 16 & 90 & $\sqrt{ }$ & \\
\hline 17 & 80 & $\sqrt{ }$ & \\
\hline 18 & 100 & $\sqrt{ }$ & \\
\hline Jumlah & 1520 & 16 & 2 \\
\hline Rata-Rata & 84,44 & \multicolumn{2}{|c|}{} \\
\hline Ketuntasan & \multicolumn{3}{|c|}{$88,88 \%$} \\
\hline
\end{tabular}

d) Refleksi

Berdasarkan hasil pengamatan pada siklus II baik guru maupun siswa sudah mengalami peningkatan dalam proses pembelajaran. Adapun hasil persentasenya sebagai berikut:

1. Hasil observasi aktivitas belajar siswa mencapai 95\%. Hal ini menunjukkan siswa sudah mulai aktif dan maksimal dalam pembelajaran

2. Kemampuan guru dalam menerapkan metode Active Knowledge Sharing sangat baik

3. Siswa sangat antusias dalam proses pembelajaran dengan metode Active Knowledge Sharing

4. Siswa semaki baik dalam bertanya, dan mengemukakan pendapatnya

Hasil evaluasi pembelajaran pembelajaran pada siklus II dengan metode Active Knowledge Sharing mengalami peningkatan dengan persentase ketuntasan klasikal mencapai mencapai 88,88\% dari 18 siswa 16 diantaranya mendapatkan skor hasil belajar diatas 73. Hasil tersebut menunjukkan bahwa pada siklus II ini secara klasikal siswa sudah tuntas dari persentase ketuntasan yang dikehendaki yaitu sebesar $75 \%$. Adanya peningkatan hasil belajar siswa ini karena siswa sudah mulai akrab dan menemuan keasyikan dengan metode Active Knowledge Sharing. Disamping itu kemampuan guru dalam mengelola proses belajar mengajar dalam metode ini juga semakin meningkat sehingga proses belajar-mengajar semakin efektif

\section{B. PEMBAHASAN}

Berdasarkan tes hasil belajar yang dilakukan tiap pembelajaran atau persiklusnya Jurnal Pendidikan Mandala diketahui bahwa siswa semakin aktif pada pertemuan berikutnya meskipun pada pertemuan pertama hasilnya kurang dari harapan. Hal ini ditandai dengan semakin meningkatnya jumlah ketuntasan. Pada siklus I persentase ketuntasan 27,78\%. Pada siklus II persentase ketuntasan $88,88 \%$. Pada tahap ini siswa sudah aktif dalam proses belajar mengajar dan siswa sudah memahami materi yang diajarkan pada materi sebelumnya.

Berdasarkan hasil observasi aktivitas belajar siswa menunjukkan peningkatan. Pada siklus I keaktifan siswa tergolong cukup aktif dengan persentase $65 \%$ karena siswa masih terpengaruh terhadap situasi di luar kelas dan tidak berusaha menjawab pertanyaan yang diberikan oleh guru. Sedangkan pada siklus II mengalami peningkatan yang tergolong sangat aktif dengan persentase $95 \%$ dikarenakan siswa telah memperbaiki kesalahan pada siklus I diantaranya tidak terpengaruh terhadap situasi di luar kelas dan berusaha menjawab pertanyaan yang diberikan oleh guru serta bertanya apabila mengalami kesulitan.

Peningkatan hasil dan aktivitas belajar merupakan tolak ukur untuk mengetahui tingkat keberhasilan siswa dalam proses belajar mengajar. Proses belajar mengajar dikatakan baik, bila proses tersebut dapat membangkitkan kegiatan belajar yang efektif. Jika dilihat dari hasil belajar yang diperoleh siswa persiklus mengalami peningkatan. Peningkatan hasil belajar dikarenakan adanya peningkatan aktivitas guru dan siswa pada siklus I dan II, artinya proses pembelajaran dengan Active Knowledge Sharing mengalami perbaikan.

Interaksi yang baik antara guru dan peserta didik memungkinkan teciptanya pembelajaran yang efektif dan efisien. Hal ini memudahkan peserta didik dalam mentransmisikan materi pelajaran, sehingga peserta didik saat memahami dan menafsirkannya kedalam suatu pemahaman yang konkrit. Dengan adanya hal ini timbulah feat back yang baik dari peserta didik.

Dengan demikian, bahwa penerapan model pembelajaran active knowledge sharing dapat mempermudah guru dalam menyampaikan informasi atau pengetahuan, tahap demi tahap dan dapat mengaitkan materi dengan situasi dunia nyata siswa dan mendorong siswa membuat hubungan antara 
pengetahuan dengan penerapan kehidupan siswa sehari-hari sehingga siswa akan merasakan pembelajaran sangat bermanfaat dan menciptakan pembelajaran menjadi lebih menarik atau menyenangkan karena siswa akan belajar melalui pengalaman bukan menghapal, dan berdampak terhadap meningkatkan aktivitas berkarya dan hasil belajar PKn.

\section{KESIMPULAN}

Berdasarkan hasil pembahasan diatas dapat disimpulkan bahwa:

1. Pembelajaran dengan metode active knowledge sharing memiliki dampak positif dalam meningkatkan hasil belajar siswa yang ditandai dengan peningkatan ketuntasan belajar siswa dalam setiap siklus, yaitu siklus I $(27,78 \%)$, siklus II $(88,88 \%)$.

2. Penerapan metode active knowledge sharing mempunyai pengaruh positif, yaitu dapat meningkatkan aktivitas belajar siswa yang ditunjukan dengan hasil observasi per siklus menunjukkan peningkatan. Pada siklus I keaktifan siswa tergolong cukup aktif dengan persentase $65 \%$. Pada siklus II mengalami peningkatan yang tergolong sangat aktif dengan persentase $95 \%$

\section{DAFTAR PUSTAKA}

Ajoku, L. I. (2013). Professional development of teachers, action planning and utilizing 21st century skills in nigerian schools. Journal of Education and Practice. 4(15), hlm 15-20.

Aprilianti, I., Haryani, R \& Widiyatmoko, F. (2013). Pengembangan Alat Peraga IPA Pada Tema Pemisahan Campuran Untuk Meningkatkan Keterampilan Proses Sains. Unnes Science Eduation Journal, USEJ 4 (2)

Aqib, 2007. Melaksanakan Penelitian Tindakan Kelas (PTK) Itu Mudah. Jakarta: Bumi Aksara.

Arikunto. S. 2006. Prosedur Penilitian Suatu Pendekatan Praktek. Jakarta:Renika Cipta.

Budiningsih, Asri. (2012). Belajar dan Pembelajaran. Jakarta: Rineka Cipta. Depdiknas, (2006). 